\title{
Ecological expertise as a factor of capitalization of land resources
}

\author{
Maria Matveeva ${ }^{1, *}$ \\ ${ }^{1}$ Irkutsk National Research Technical University, 664074, Lermontova str., 83, Irkutsk, Russia
}

\begin{abstract}
Ecological expertise is considered as a factor of the capitalization of land resources. The conducted research shows that without taking into account the environmental component of the national economy, the process of involving and capitalization of land resources in the economic circulation within the framework of the land development mechanism cannot be realized. The principles of ecological expertise in the article are presented in the form of a scheme. The introduction of green standards for the construction of Olympic facilities and infrastructure in Sochi is the most relevant example of the synthesis of economic, environmental and innovative aspects. Comparative characteristics of the international green standards BREEAM and LEED* (*BREAM (British Building Research Establishment Environmental Assessment Method) are presented. Comparative analysis showed that the BREEAM standard presupposes very stringent requirements (clearly formulated, not allowing deviations, a complicated cumbersome system, the high cost of obtaining approvals), while the LEED Standard is adapted only for the social and economic realities of the United States and provides for stringent requirements for the preparation of documentation, the lack of an independent audit of the evaluation activities; hard link of functionality with architectural forms that are not always acceptable outside of the USA. The application of green standards makes it possible to significantly increase the market value of land plots and necessitates the application of these standards in the development and implementation of investment and construction projects and programs.
\end{abstract}

Synthesis of various types of activities in order to obtain synergy effects becomes a necessary condition for ensuring the system-functional integrity of modern economic phenomena. The process of involving the land resources in the economic circulation and capitalization within the framework of the land-development mechanism cannot be realized without taking into account the environmental component of the national economy [1].

As for the current assessment of the ecological expertize, in addition to the Federal Law "On Environmental Expertise", such documents as the Urban Planning, Land, Forest and Water Codes, laws and decrees of the President of the Russian Federation, resolutions of the Government of the Russian Federation, orders of ministries and departments, state standards, other normative acts (Table 1) also compile the normative and regulatory basis.

\footnotetext{
${ }^{*}$ Corresponding author: expertiza@ istu.edu
} 
In Russia, on the whole, an institutional basis for recording environmental constraints has been created as an element of the targeted focus of investment and construction activities within the framework of land development. At the same time, land development is distinguished with its inherent principles, the complex novelty of which gives the property of the organizational innovation to land-development. Its dynamic projection is currently characterized by the imposition of the principles of environmental (ecological) assessment (expertise).

Table 1. Main regulatory legal acts of the Federal level in the field of ecological expertise in the Russian Federation.

\begin{tabular}{|c|c|c|}
\hline Regulatory legal act & Year & $\begin{array}{l}\text { The body of the state power that } \\
\text { adopted (approved) the document }\end{array}$ \\
\hline $\begin{array}{l}\text { The Law of the Russian Soviet } \\
\text { Federative Socialist Republic "On } \\
\text { Environmental Protection" }\end{array}$ & $\begin{array}{l}1991 \\
1993\end{array}$ & $\begin{array}{l}\text { The Supreme Council of the } \\
\text { Russian Soviet Federative } \\
\text { Socialist Republic }\end{array}$ \\
\hline $\begin{array}{l}\text { Regulation on the Environmental } \\
\text { Impact Assessment in the Russian } \\
\text { Federation (in force until May 2000) }\end{array}$ & 1994 & $\begin{array}{l}\text { The Ministry of Natural } \\
\text { Resources of the Russian } \\
\text { Federation, approved by the } \\
\text { Ministry of Justice of the Russian } \\
\text { Federation }\end{array}$ \\
\hline $\begin{array}{l}\text { Instructions for the environmental } \\
\text { justification of economic and other } \\
\text { activities }\end{array}$ & 1995 & $\begin{array}{c}\text { The Ministry of Natural } \\
\text { Resources of the Russian } \\
\text { Federation }\end{array}$ \\
\hline $\begin{array}{l}\text { The Federal Law "On the } \\
\text { Environmental Expertise" }\end{array}$ & 1995 & $\begin{array}{l}\text { Legislative Assembly of the } \\
\text { Russian Federation }\end{array}$ \\
\hline $\begin{array}{l}\text { Regulations on the procedure of the state } \\
\text { environmental expertise }\end{array}$ & 1996 & $\begin{array}{l}\text { The Government of the Russian } \\
\text { Federation }\end{array}$ \\
\hline $\begin{array}{l}\text { List of regulatory documents } \\
\text { recommended for use in conducting } \\
\text { state environmental expertize, as well as } \\
\text { in drawing up an environmental } \\
\text { justification for economic and other } \\
\text { activities }\end{array}$ & 1997 & $\begin{array}{c}\text { The State Committee for } \\
\text { Environmental Protection of the } \\
\text { Russian Federation }\end{array}$ \\
\hline $\begin{array}{l}\text { Regulation on the assessment of the } \\
\text { impact of planned economic and other } \\
\text { activities on the environment in the } \\
\text { Russian Federation }\end{array}$ & 2000 & $\begin{array}{l}\text { The State Committee for } \\
\text { Environmental Protection of the } \\
\text { Russian Federation, approved by } \\
\text { the Ministry of Justice of the } \\
\text { Russian Federation }\end{array}$ \\
\hline $\begin{array}{l}\text { Regulation of the state environmental } \\
\text { expertize }\end{array}$ & 2008 & $\begin{array}{c}\text { The Ministry of Natural } \\
\text { Resources of the Russian } \\
\text { Federation }\end{array}$ \\
\hline
\end{tabular}

The principles of the ecological expertize, proceeding from the Article 3 of the Federal Law "On the Environmental Expertise" are shown in the form of a scheme on the Figure 1. 


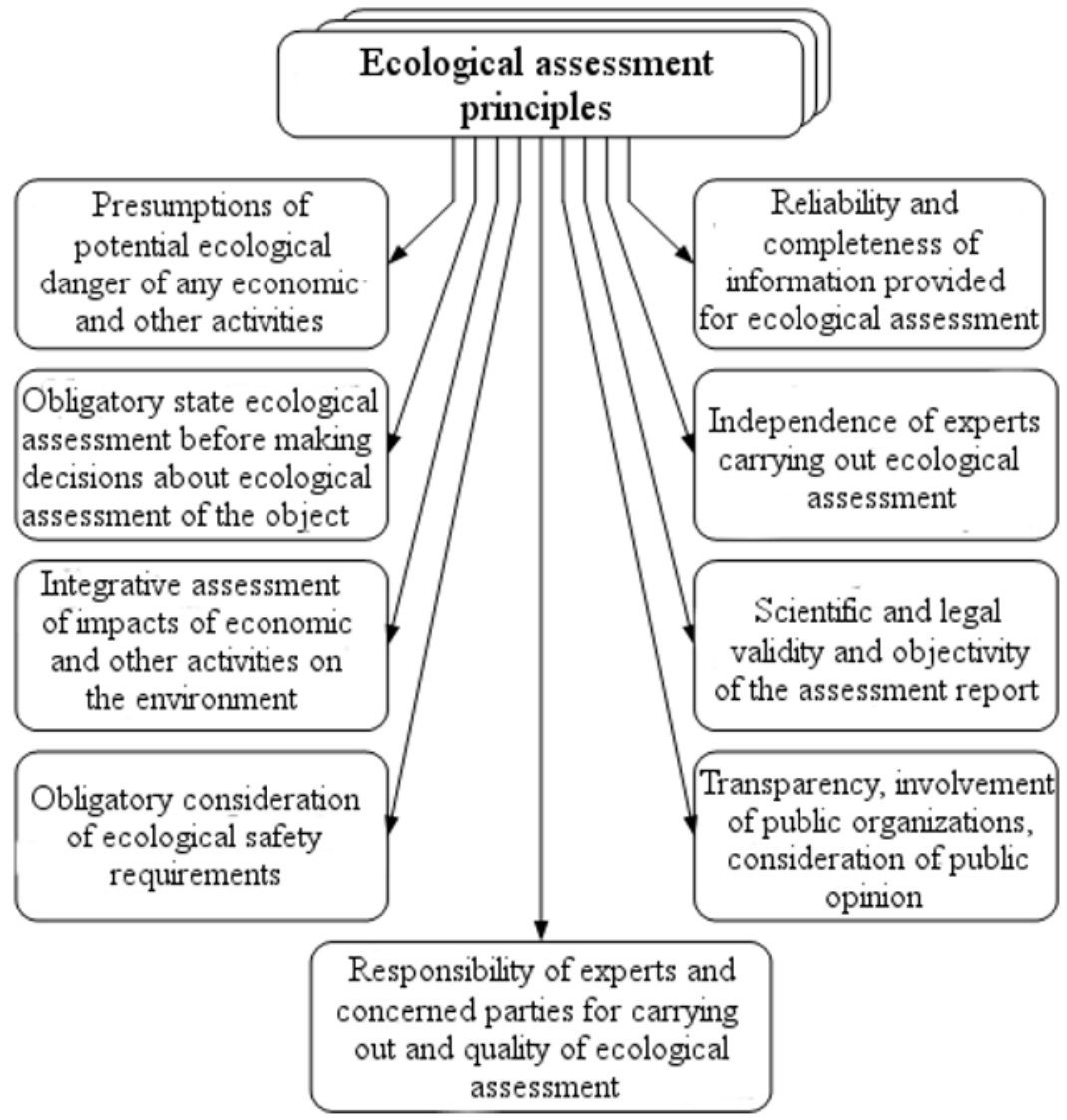

Fig. 1 Principles of ecological expertise.

Methodological approaches to the development of environmental rules and regulations, which have just begun forming in the Russian Federation, to some extent determine the environmental and economic conditions for the implementation of investment and construction projects within the limits of natural complexes. But, unfortunately, they are extremely poorly developed and still require a balance of production and environmental potentials, where production growth would acquire an environment-friendly function. Often, the territorial environmental regulation is not aimed at the expansion of ecological and economic equifinality, based on the balanced use of land resources, but is focused on the unilateral economic efficiency and the accelerated return on investment.

Overcoming the current situation is being done through the use of restraining measures. Currently, the practice has developed various methods of limiting and using land plots: economic, urban, environmental and social ones.

Environmental restrictions in land use are established by regulatory legal acts. In accordance with them, the use of land in protected areas is either completely impossible, or imposes a number of restrictions. It is proposed to refine the value of land at the regional level, taking into account all the details and specifics of the plot of land. This means that the classification of land and the legal fixation of its results in relation to individual plots of land should be attributed more to the tasks of regional legislation [2]. In this case, the account the environmental factor in the land development can be implemented, fixing a profit reasonable for the territory, without violating the natural features of the plot. 
The essence of the economic limitations of the development of the territory is the following: to support the rates of economic growth, it would be necessary to use restrictions on the choice of territories for development, as there are no territories, prepared for economic activities in respect of engineering and transport.

Methods of environmental constraints in economic activities in land development are widely spread abroad. For example, in Switzerland and in a number of other countries, a number of restrictions were imposed on the additional allocation of new land for road construction and for emissions of pollutants into the environment, including automobile transport. In the United States, the National System for the discharge of pollutants into the aquatic environment can issue permits for wastewater discharge. The UAE conducts construction and development of the adjacent territories of the eco-city, which in future will provide itself with clean electricity.

According to our opinion [3], the most relevant example of the synthesis of economic, ecological and innovative aspects is, of course, the introduction of green standards for the construction of Olympic facilities and infrastructure in Sochi.

The first green standard became the basic document of the national green standard. Along with Russian environmental legislation, the standard took into account the international green standards of BREEAM and LEED. The British Building Research Establishment Environmental Assessment Method is the first of all environmental assessment systems, which has undergone significant changes since its inception in 1990. They are embodied in new certification systems.

LEED (The Leadership in Energy \& Environmental Design) is the Guidelines for Energy and Environmental Design, a rating system for the certification of green buildings. The system is developed as the Green Building Standard for Measuring Energy Efficiency, Environmental Purity and Sustainability by the United States Green Building Council (USGBC) in 1993. The BREEAM and the LEED environmental certification systems are compared in the Table 2.

Table 2. Comparative characteristics of the BREEAM and the LEED environmental certification systems.

\begin{tabular}{|c|c|c|}
\hline & $\begin{array}{l}\text { The BREEAM standard } \\
\text { (established in 1990) }\end{array}$ & $\begin{array}{l}\text { The LEED standard } \\
\text { (established in 1998) }\end{array}$ \\
\hline $\begin{array}{c}\text { Available circuitry } \\
\text { of assessments }\end{array}$ & $\begin{array}{l}\text { Offices; } \\
\text { Retail space; } \\
\text { Industrial facility; } \\
\text { Educational institution; } \\
\text { Eco-homes (code for } \\
\text { sustainable homes); } \\
\text { Healthcare facilities; } \\
\text { Projects for individual order; } \\
\text { Multi-story buildings; } \\
\text { Objects of international } \\
\text { importance; } \\
\text { Courts; } \\
\text { Prisons. }\end{array}$ & $\begin{array}{l}\text { New construction; } \\
\text { Operation of already constructed } \\
\text { buildings; } \\
\text { Commercial space; } \\
\text { Interior design; } \\
\text { Finishing of buildings (shell \& } \\
\text { core); } \\
\text { Schools; } \\
\text { Retail space (retail); } \\
\text { Healthcare facilities; } \\
\text { Residential real estate; } \\
\text { Development of suburban housing } \\
\text { construction (cottage settlements). }\end{array}$ \\
\hline Categories & $\begin{array}{l}\text { Management; } \\
\text { Health and social welfare; } \\
\text { Energy; } \\
\text { Transport; } \\
\text { Water delivery; } \\
\text { Materials; }\end{array}$ & $\begin{array}{l}\text { Ensuring environmental } \\
\text { sustainability of design } \\
\text { (sustainable sites); } \\
\text { Efficient use of water; } \\
\text { Energy and the impact of energy } \\
\text { use on the atmosphere; }\end{array}$ \\
\hline
\end{tabular}




\begin{tabular}{|c|c|c|}
\hline & $\begin{array}{l}\text { Waste; } \\
\text { Effective management of } \\
\text { built-up areas and ecology; } \\
\text { Pollution control of the } \\
\text { environment. }\end{array}$ & $\begin{array}{l}\text { Materials and resources; } \\
\text { Creating a favorable atmosphere } \\
\text { inside the building; } \\
\text { Application of innovations in } \\
\text { design. }\end{array}$ \\
\hline $\begin{array}{l}\text { The level of } \\
\text { compliance with the } \\
\text { standards assigned } \\
\text { to the objects by } \\
\text { rating evaluation } \\
\text { systems (from the } \\
\text { lowest to the highest } \\
\text { level }\end{array}$ & $\begin{array}{l}\text { "Certified"; } \\
\text { "Good"; } \\
\text { "Very good"; } \\
\text { "Excellent"; } \\
\text { "Outstanding" }\end{array}$ & $\begin{array}{l}\text { "Certified"; } \\
\text { "Silver" certificate; } \\
\text { "Golden" certificate; } \\
\text { "Platinum" certificate. }\end{array}$ \\
\hline $\begin{array}{l}\text { Organization of the } \\
\text { evaluation works }\end{array}$ & Trained evaluators & $\begin{array}{l}\text { US-GBC (American Council for } \\
\text { green buildings) }\end{array}$ \\
\hline QA/Certification & BRE & US-GBC \\
\hline $\begin{array}{l}\text { The amount of } \\
\text { objects that received } \\
\text { certificates by the } \\
\text { standards (data for } \\
\text { February 2008). }\end{array}$ & $\begin{array}{l}110,808 \text { objects (of which } \\
109,450 \text { - in the UK) }\end{array}$ & $\begin{array}{l}1,823 \text { (of which } 1,823 \text { - in the } \\
\text { USA) }\end{array}$ \\
\hline $\begin{array}{c}\text { Schemes of } \\
\text { evaluation systems. } \\
\text { Weaknesses. }\end{array}$ & $\begin{array}{l}\text { Very strict requirements } \\
\text { (clearly formulated, not } \\
\text { allowing deviations); } \\
\text { Complex and cumbersome } \\
\text { system; } \\
\text { Market profile; } \\
\text { High cost of obtaining } \\
\text { approvals. }\end{array}$ & $\begin{array}{c}\text { Adapted only for the socio- } \\
\text { economic realities of the United } \\
\text { States; } \\
\text { Strict requirements for } \\
\text { documentation; } \\
\text { There is no independent audit of } \\
\text { evaluation activities; } \\
\text { Rigid connection of the functional } \\
\text { purpose with architectural forms, } \\
\text { which is not always acceptable } \\
\text { outside the US. }\end{array}$ \\
\hline $\begin{array}{c}\text { Schemes of } \\
\text { evaluation systems. } \\
\text { Strengths. }\end{array}$ & $\begin{array}{l}\text { The assessment system is } \\
\text { applicable to various types } \\
\text { of buildings; } \\
\text { Possibility of independent } \\
\text { auditing; } \\
\text { The criteria are "tuned" to } \\
\text { the British law and British } \\
\text { values; } \\
\text { Individual approach to } \\
\text { certain objects that allows } \\
\text { comparing different } \\
\text { buildings. }\end{array}$ & $\begin{array}{l}\text { A good system of promotion at the } \\
\text { transnational level; } \\
\text { A large amount of information on } \\
\text { the work of the evaluation } \\
\text { commissions and on the LEED } \\
\text { itself is in the public domain; } \\
\text { There is no need to organize the } \\
\text { training of appraisers. }\end{array}$ \\
\hline
\end{tabular}

It follows from the analysis that, if according to the BREEAM standards, offices, retail areas, industrial facilities, general educational institutions, eco-houses (code for sustainable homes), objects of public health, projects for individual orders, multi-story houses, objects of international importance, courts, and prison are classified as available evaluation schemes, the LEED standard includes new construction, the operation of already constructed buildings, commercial areas, interior design, finishing of buildings (shell \& core), schools, retail areas, 
objects of public health, residential estate, and development of suburban housing construction (cottage settlements).

Analyzing the schemes of evaluation systems, we have to note that the BREEAM standard presupposes very strict requirement (clearly formulated and not allowing deviations), the market profile, the high cost of obtaining approvals and it is a complicated cumbersome system, while the LEED standard is adapted only for the social and economic realities of the USA and provides for stringent requirements for the execution of documentation, the lack of independent audit of evaluation activities, a rigid relationship between functional purpose and architectural forms, which is not always acceptable outside the United States. At the same time, to the weak sides of the standard, BREEAM we refer very stringent requirements (clearly formulated and not allowing deviations), a market profile, a high cost of obtaining approvals, and that this is a complicated cumbersome system. According to the LEED standard, the weaknesses can be noted as the following: it is adapted only for the social and economic realities of the United States, it contains strict requirements for documentation, there is no independent audit of evaluation activities, and there is rigid connection of functional purpose with architectural forms, which is not always acceptable outside the US.

The strengths of the BREEAM standard include the following: the assessment system is applicable to various types of buildings, it provides with a possibility of independent auditing, the criteria are "tuned" to the British law and British values, and there is an individual approach to certain objects that allows comparing different buildings. The positive aspects of the LEED standard are the facts that it possesses a good system of promotion at the transnational level, there is a large amount of information on the work of evaluation commissions and about the LEED itself in the public domain, and there is no need to organize the training of appraisers.

In Russia, additional environmental requirements of these standards for the first time were accepted and implemented in ten internationally recognized and certified facilities with specific innovative solutions and indicators of environmental and economic efficiency. A positive example of the environmental and innovative focus of the Olympic construction is certainly important. But, firstly, the methods of environmental and innovation focus of investment and construction activities were only fragmentarily used at the stage of the land development of the Olympic facilities, and secondly, the organizational aspects of the synchronization of participants of the investment and construction activities were at the epicenter of attention only with respect to the specialized facilities [19].

Thus, the application of green standards makes it possible to significantly increase the market value of land plots and necessitates the application of these standards in the development and implementation of investment and construction projects and programs.

\section{References}

1. M. V. Matveeva, Izvestia IGEA, 4, 159-164 (2013)

2. M. I. Kamenetsky, N. Yu. Yaskova, Land-development and investment-construction activity: the problem of effective interaction (MAX Press, Moscow, 2012)

3. M. V. Matveeva, Target focus as a tool for implementing national development priorities (Irkutsk State Technical University, Irkutsk, 2013)

4. Convention of the United Nations Economic Commission for Europe "On Access to Information, Public Participation in Decision-Making and Access to Justice in Environmental Matters" (http: //www.un.org/en/documents/decl_conv/conventions/orh us.shtml) 
5. The concept of socio-economic development of the country until 2020 (http://www.ifap.ru/ ofdocs / rus / rus006.pdf)

6. F. Bacon, The Essays or counsels civil and moral (London, 1625)

7. G. F. Davis, Managed by the Markets: How Finance reshaped America (Oxford University Press, Oxford, 2009)

8. Fraassen Bas C. van. Empiricism in the Philosophy of Science, Images of Science (Clarendon Press, 1980)

9. G. W. F. Hegel, Wissenschaft der Logik. Werke. Zweite Auflage. Bande III, IV, V (Berlin, 1841)

10. K. Jonca, Die Radikalisierung des Antisemitismus. Der Fall Herschel Grynszpan und die "Reichskristallnacht" (Bundeszentrale für politische Bildung, Bonn, 1990).

11. J. M. Keynes, General Theory of Employment, Interest and Money (1936)

12. T. S. Kuhn, The Structure of Scientific Revolutions (University of Chicago Press, Chicago, 1962)

13. S. Lumby, C. Jones, Corporate finance: theory \& practice (Thomson, London, 2006)

14. K. Marx, Misère de la philosophie. Réponse à la philosophie de la misère de M. Proudhon (Paris - Bruxelles, 1847)

15. A. V. Bogoviz, S. V. Lobova, A. N. Alekseev, I. A. Koryagina, T. V. Aleksashina, Advances in Intelligent Systems and Computing, 622, 609-616 (2018)

16. K. Mellhi, K. Morrell, G. Wood, The Ethical Business (Palgrave, London, 2010)

17. J. Mill, Elements of political economy (London, 1821)

18. A. Rasche, G. Kell, The UN Global Compact: Achievements, trends and Challenges (Cambridge University Press, Cambridge, 2010)

19. D. V. Dayneko, A. I. Dayneko, V. V. Peshkov, N. Ya. Kalyuzhnova, Proceedings of Universities. Investment. Construction. Real Estate, 3(22), 16-120 (2017) 